\title{
Laboratory techniques in the diagnosis and assessment of hepatitis B virus infection
}

\author{
J J Gray, T G Wreghitt
}

\section{Introduction}

The discovery of Australia antigen (hepatitis B surface antigen ( $\mathrm{HBsAg}$ )) by Blumberg in $1965,{ }^{1}$ its association with serum hepatitis described by Prince in $1968^{2}$ and the visualisation of the $42 \mathrm{~nm}$ infectious hepatitis $B$ virus (HBV) particle by electron microscopy in $1970^{3}$ led to research into the aetiology, treatment and prevention of serum hepatitis. Further serological markers of $\mathrm{HBV}$ and its mode of replication have been described, ${ }^{45}$ the HBV genome cloned ${ }^{6}$ and effective vaccines produced. ${ }^{7}$

HBV infection is endemic in certain geographical areas with approximately 300 million HBsAg carriers worldwide. The carrier rate varies from country to country with $0 \cdot 2-0.5 \%$ in Western Europe and 8-20\% in South East Asia. Rates are generally higher in the tropics, amongst males and in urban communities.

HBV infection may be symptomatic or asymptomatic and is associated with a wide spectrum of inflammatory liver disease. This ranges from acute to chronic hepatitis and may ultimately lead to cirrhosis or primary hepatocellular carcinoma. In acute symptomatic infections, patients may present with malaise, lethargy, anorexia, headache, mild diarrhoea or upper right quadrant pain followed by jaundice and arthralgia.

The detection of HBV markers in the serum of patients with HBV infection is not only important for diagnosis but also for management and predicting the outcome of infection.

\section{Hepatitis $B$ markers}

HBsAg may be detected in the blood 2 to 8 weeks before the onset of hepatitis and persists during the acute phase. It is usually cleared from the bloodstream during the convalescence period when antibodies to hepatitis B surface antigen (anti-HBs) become detectable. Failure to clear $\mathrm{HBsAg}$ within six months usually indicates a chronic $\mathrm{HBsAg}$ carrier state although HBsAg may be present in some acute cases for up to 12 months. Hepatitis B core antigen ( $\mathrm{HBcAg}$ ) is not detected in the serum or plasma although a soluble component of the core protein, $\mathrm{HBeAg}$, may be found a few days after the appearance of HBsAg. HBV DNA and DNA polymerase are also detected at this time and their presence, like that of $\mathrm{HBeAg}$, indicates high infectivity. In an uncomplicated acute $\mathrm{HBV}$ infection HBeAg is usually cleared from the serum or plasma within 6 weeks but as with HBsAg it may persist in the carrier state.

The immune response to HBV infection is characterised in the first instance by the appearance of $\operatorname{IgM}$ antibodies to $\mathrm{HBcAg}$ (anti-HBc IgM) followed by anti-HBc IgG which may persist for life. As anti-HBc is not a neutralising antibody its presence does not preclude active viral replication nor the presence of infectious virus in the blood. However, the presence of antibody to hepatitis $\mathrm{Be}$ antigen (anti-HBe), which appears after anti-HBc and is also a nonneutralising antibody, usually correlates with a reduction in viral replication and the resolution of abnormal liver function in an acute resolving infection. Anti-HBe may persist for several months but eventually is undetectable in serum or plasma. HBV mutants, defective in the expression of the pre-core region of the $\mathrm{C}$ gene, necessary for excretion of $\mathrm{HBeAg}$, have been associated with chronic anti-HBe positive hepatitis B (HBeAg minus mutant). ${ }^{8}$ Anti-HBs is a neutralising antibody and its presence indicates recovery from infection and protection against reinfection. It is also produced in response to vaccination with plasma-derived or recombinant HBV vaccines. Therefore, the detection of anti-HBs in the absence of all other HBV markers indicates a response to vaccination.

Antigen expression may be prolonged and the production of antibodies to these antigens delayed in chronic HBV infection. Table 1 describes the interpretation of the serological markers detected after acute and chronic HBV infection and figure 1 demonstrates the relative concentrations of these serological markers.
Clinical Microbiology and Public Health Laboratory, Addenbrooke's Hospital, Hills Road, Cambridge CB2 2QQ, UK

J J Gray

T G Wreghitt

Correspondence to Dr J J Gray

Accepted for publication 30 January 1992
Table 1 Serological markers in hepatitis B virus infection

\begin{tabular}{|c|c|c|c|c|c|c|}
\hline & $\begin{array}{l}\text { HBV DNA/DNA } \\
\text { polymerase }\end{array}$ & $H B s A g$ & $\mathrm{HBeAg}$ & Anti-HBe & Anti-HBc & Anti-HBs \\
\hline Incubation period & + & + & $+1-$ & - & - & - \\
\hline Acute infection & + & + & + & _- & + & - \\
\hline Convalescence & - & $+1-$ & - & + & + & + \\
\hline History of past infection & - & -1 & - & + & + & $+1-$ \\
\hline History of vaccination & _- & - & - & - & - & +1 \\
\hline Carrier state (high infectivity) & + & + & + & _- & + & I \\
\hline Carrier state (low infectivity) & $+1-$ & + & - & + & + & - \\
\hline
\end{tabular}


Figure 1 The relative concentrations of $H B V$ markers during acute and chronic $H B V$ infection.

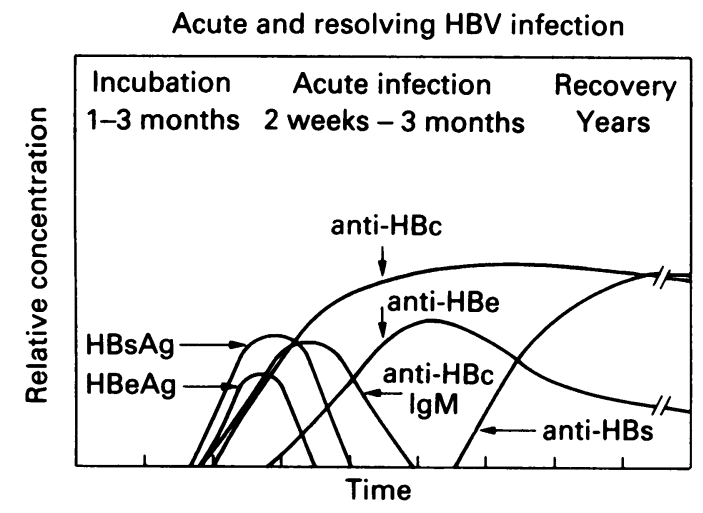

Chronic HBV infection indicating high infectivity

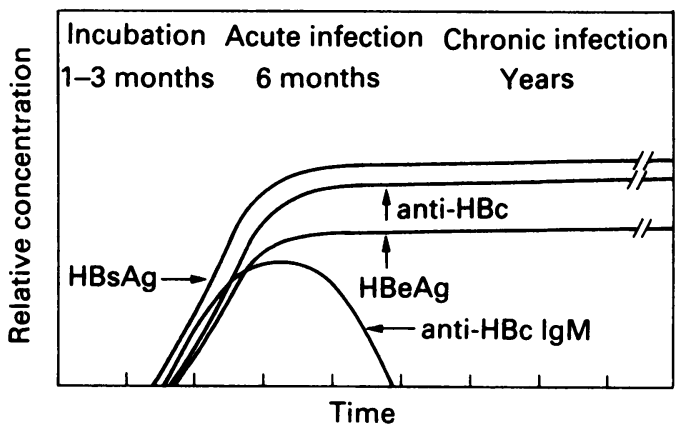

Chronic HBV infection indicating low infectivity

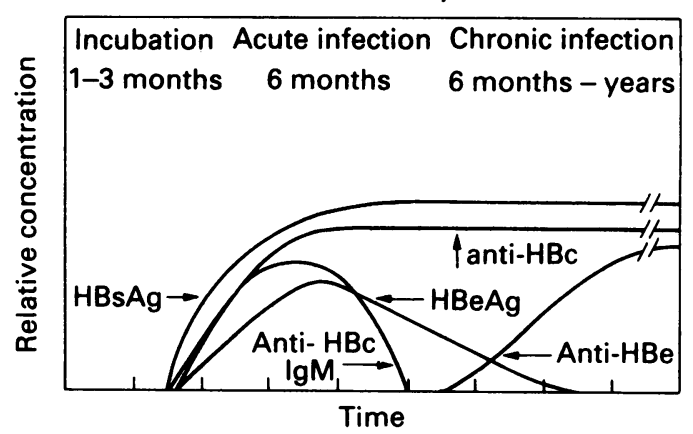

Laboratory techniques

As HBV cannot be isolated with conventional cell culture techniques, serological and molecular biological methods have been applied for detecting HBV markers.

\section{Detection of $\mathrm{HBs} \mathrm{Ag}$}

Techniques for detecting $\mathrm{HBsAg}$ are classified as first, second and third generation assays with first generation assays being the least sensitive. Agar gel diffusion, a first generation assay, is relatively insensitive and is now used mainly for characterising sub-type determinants of $\mathrm{HBsAg} .{ }^{9}$ Although second generation assays such as counter immunoelectrophoresis ${ }^{10}$ and reverse passive latex agglutination ${ }^{11}$ are 5-10 times more sensitive than agar gel diffusion for detecting $\mathrm{HBsAg}$ they have been superseded by the more sensitive third generation assays. These assays which include reverse passive haemagglutination (RPH), radioimmunoassay (RIA), enzyme-linked immunosorbent assay (ELISA) and enhanced chemiluminescence are 50-100 times more sensitive than agar gel diffusion and are used in a majority of laboratories for detecting HBsAg.
In RPH anti-HBs is coupled to red blood cells in the presence of chromic chloride ${ }^{12}$ or tannic acid. ${ }^{13}$ The resulting anti-HBs-coupled red blood cells, which are agglutinated in the presence of $\mathrm{HBsAg}$, are stable and may be

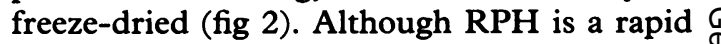
and simple assay to perform it is prone to false-positive reactions. For this reason, control cells, prepared by coupling an anti-HBs negative immunoglobulin, derived from the 3 same species, to red blood cells, should always $\stackrel{0}{\circ}$ be tested in parallel with the anti-HBs- $\Rightarrow$ coupled red blood cells. The sensitivity of RPH may vary from 5-50 ng $\mathrm{HBsAg} / \mathrm{ml}$ serum.

RIAs, ${ }^{14}$ ELISAs $^{15}$ and assays employing enhanced chemiluminescence ${ }^{16}$ capture HBsAg from the serum or plasma by means of anti-HBs bound to a solid phase. Captured 0 HBsAg is then detected with a second $\overrightarrow{\vec{\omega}}$ antibody, labelled with a radioisotope in RIAs or an enzyme in ELISAs or chemiluminescent assays (fig 3). These assays can detect $\leqslant \operatorname{lng} \underset{\infty}{\infty}$ $\mathrm{HBsAg} / \mathrm{ml}$ serum or plasma. The solid phase may be a microtitre well, bead, cuvette or $\underset{\omega}{\mathcal{N}}$ microcarrier, manufactured from polyvinyl, polycarbonate, polystyrene or nylon. AntiHBs antibodies used in solid-phase capture immunoassays, both to capture $\mathrm{HBsAg}$ and 0 detect its capture, were originally polyclonal $\stackrel{\infty}{\oplus}$ and had to be produced in two different species $\vec{\theta}$ (such as horse and goat) to reduce crossreactivity and non-specific binding. Polyclonal animal sera have been replaced in most assays by monoclonal antibodies of high specificity and affinity, directed against specific epitopes of HBsAg. ${ }^{17}$ In RIA, the detector antibody is $\stackrel{\square}{\circ}$ labelled with a radioisotope. Iodine-125, $\overrightarrow{\vec{A}}$ which has a half-life of approximately 60 days, is the most commonly used isotopic label. Although RIAs combine high specificity and sensitivity, problems associated with the safe on handling and disposal of radioactive materials

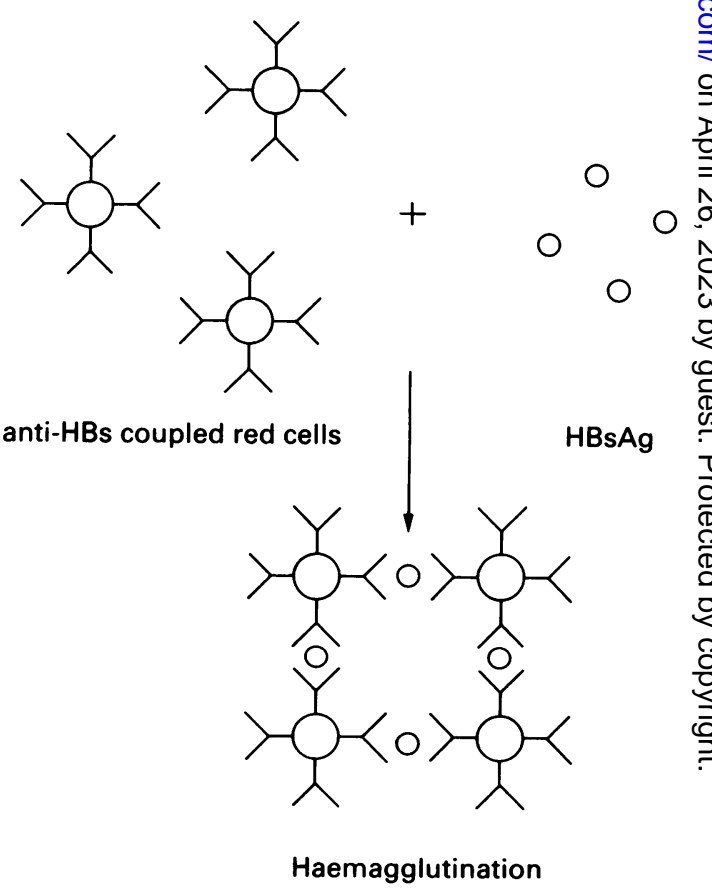

Figure 2 Reverse passive haemagglutination for detecting $\mathrm{HBs} \mathrm{Ag}$. 


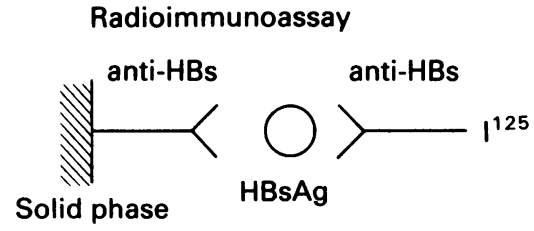

Gamma radiation
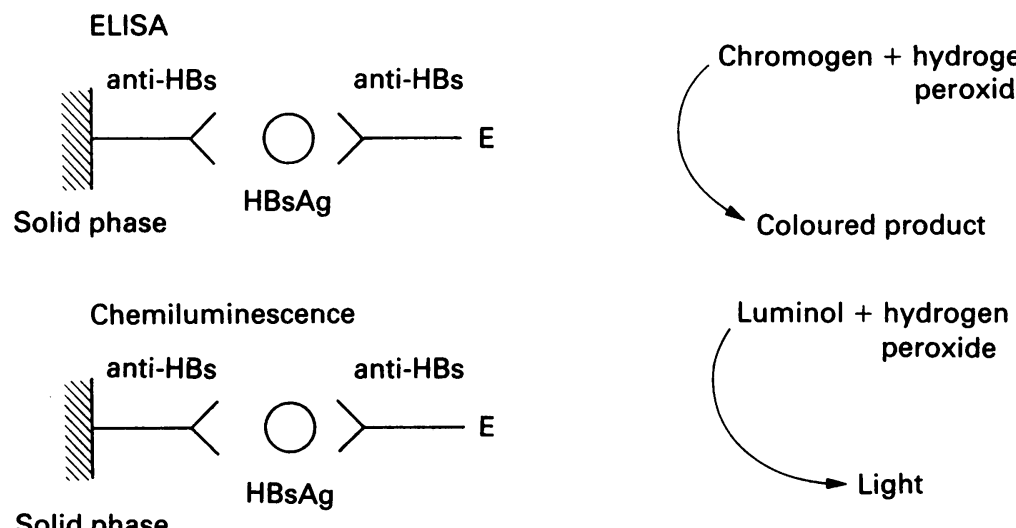

Solid phase

$1^{125}:$ radioisotope of iodine $\quad E$ : enzyme-horseradish peroxidase

Figure 3 Immunoassays for detecting $\mathrm{HBs} A \mathrm{~g}$.

as well as the short shelf-life of the radiolabelled antibody make them less attractive than ELISAs for the routine detection of HBsAg. ELISAs exhibit comparable sensitivity and specificity, use stable enzymelabelled antibodies and have a comparatively long shelf-life.

ELISAs for detecting antigen can be made more sensitive by enzyme amplification. This may be achieved by allowing the bound enzyme to catalyse the formation of a colourless reaction product which in turn catalyses a colour-forming reaction. ${ }^{18}$ Alternatively, the avidin-biotin system, which makes use of the high affinity of avidin for biotin, can be used to increase the number of enzyme molecules
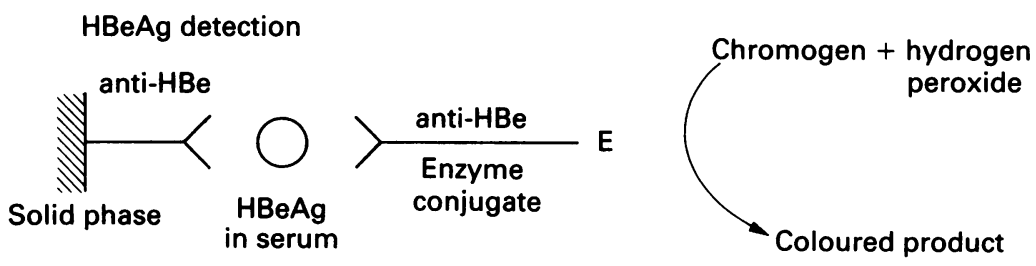

anti-HBe detection

a. anti-HBe positive sample

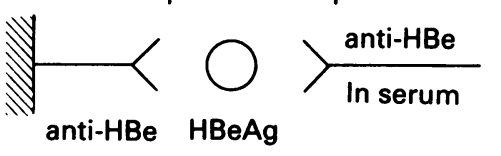

No colour

b. anti-HBe negative sample
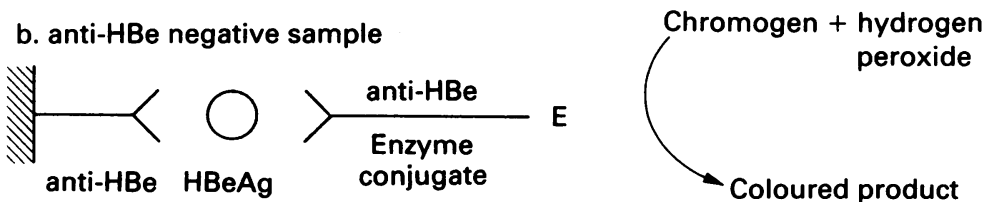

Figure 4 Enzyme immunoassay for detecting $\mathrm{HBe} \mathrm{Ag}$ and anti-HBe. bound and therefore produce a higher signal in the presence of enzyme substrate. ${ }^{19}$ In ELISAs which use enhanced chemiluminescence, emitted light may be detected in less than one minute compared to $20-30$ minutes for a colour reaction to develop in a conventional ELISA.

The specificity of assays in current use will vary from manufacturer to manufacturer. In general, the specificity of enzyme immunoassays may depend on the condition of the specimen. Haemolysed serum/plasma or serum/plasma containing red blood cells or bacteria may contain endogenous enzymes which react with the enzyme substrate and produce false-positive reactions. Samples containing the preservative sodium azide, a potent peroxidase poison, may produce falsenegative results in assays that use a peroxidase-labelled second antibody. Therefore, it is important to perform confirmatory tests on all reactive samples. Although this may be achieved by performing an alternative assay of similar sensitivity, a neutralisation test with anti-HBs is preferred.

\section{Detection of $\mathrm{HBeAg}$ and anti-HBe}

The detection of $\mathrm{HBeAg}$ and anti-HBe is usually accomplished in a single assay. The patient's serum is added to two wells of a microtitre plate coated with anti-HBe monoclonal antibodies. Anti-HBe monoclonal antibody conjugated to horseradish peroxidase is added to the first well to detect $\mathrm{HBeAg}$. To detect anti-HBe, $\mathrm{HBeAg}$ is added to the second well followed by the anti-HBe enzyme conjugate. Competition between anti-HBe present in the patient's serum and the anti-HBe enzyme conjugate will result in a decrease in colour (fig 4).

\section{Detection of anti- $\mathrm{HBC}$}

Anti-HBc may be the only serological marker present at certain times during the course of infection with $\mathrm{HBV}$ (fig 1). Anti-HBc can be detected when $\mathrm{HBsAg}$ is no longer detectable and anti-HBs has not yet reached detectable levels. This time is often referred to as the "core window". Also, later in the course of HBV infection when both HBsAg and antiHBs may not be detectable the only evidence of past infection is the presence of anti-HBc.

Anti-HBc, IgM, whose presence indicates active viral replication in the acute or chronic phases of HBV infection may be detected by means of a u-capture RIA or ELISA. Wells of a microtitre plate, coated with anti-human IgM (u-chain specific) are used to capture IgM from the patient's serum. HBcAg is then added and will bind to any anti-HBc IgM present. Bound $\mathrm{HBcAg}$ can then be detected with a radio- or enzyme-labelled anti-HBc monoclonal antibody.

Total anti-HBc is usually detected in a competitive RIA or ELISA. Anti-HBc present in the patient's serum and a radio- or enzymelabelled anti-HBc compete for $\mathrm{HBcAg}$ bound to the solid phase. Therefore the proportion of conjugate bound to the $\mathrm{HBcAg}$ is inversely 
Table 2 Response to vaccination with $H B V$ vaccines

\begin{tabular}{|c|c|c|}
\hline $\begin{array}{l}\text { Anti-HBs } \\
\text { concentration } \\
(m I U / m l)\end{array}$ & Response & Comment \\
\hline $\begin{array}{l}>100 \\
\quad 10-100 \\
<10\end{array}$ & $\begin{array}{l}\text { Good } \\
\text { Poor } \\
\text { None }\end{array}$ & $\begin{array}{l}\text { Booster dose recommended in } 5 \text { years } \\
\text { Give a booster dose immediately and retest in 1-3 months } \\
\text { Give a booster dose immediately and if no response in } 1-3 \\
\text { months advise "not protected". Consider another dose of } \\
\text { vaccine and retest }\end{array}$ \\
\hline
\end{tabular}

«If vaccinees are monitored give booster dose when the concentration of anti-HBs falls below $10 \mathrm{mIU} / \mathrm{ml}$.

proportional to the concentration of anti-HBc present.

\section{Detection of anti-HBs}

Assays to detect anti-HBs were initially used to indicate clearance of $\mathrm{HBsAg}$ in persons with previous HBV infection. However, since the introduction of $\mathrm{HBV}$ vaccines, these tests are used increasingly to demonstrate an immune response after vaccination with plasma-derived or recombinant $\mathrm{HBV}$ vaccines.

Seroconversion rates, after vaccination, vary between $80-100 \%$ in healthy adults and the persistence of anti-HBs is related to the peak antibody concentrations after vaccination. ${ }^{20}$ Therefore, any assay used to detect anti-HBs should be quantitative to allow vaccinees with an inadequate response as well as those who do not mount an immune response to be identified. HBV infections, associated with escape mutants, have been reported in patients who had previously developed adequate levels of anti-HBs after vaccination. ${ }^{21}$ The viruses associated with these infections have a mutation in the highly antigenic "a" determinant of HBsAg.

The patient's serum is added to a well of a microtitre plate coated with $\mathrm{HBsAg}$ and any bound anti-HBs detected with enzyme-

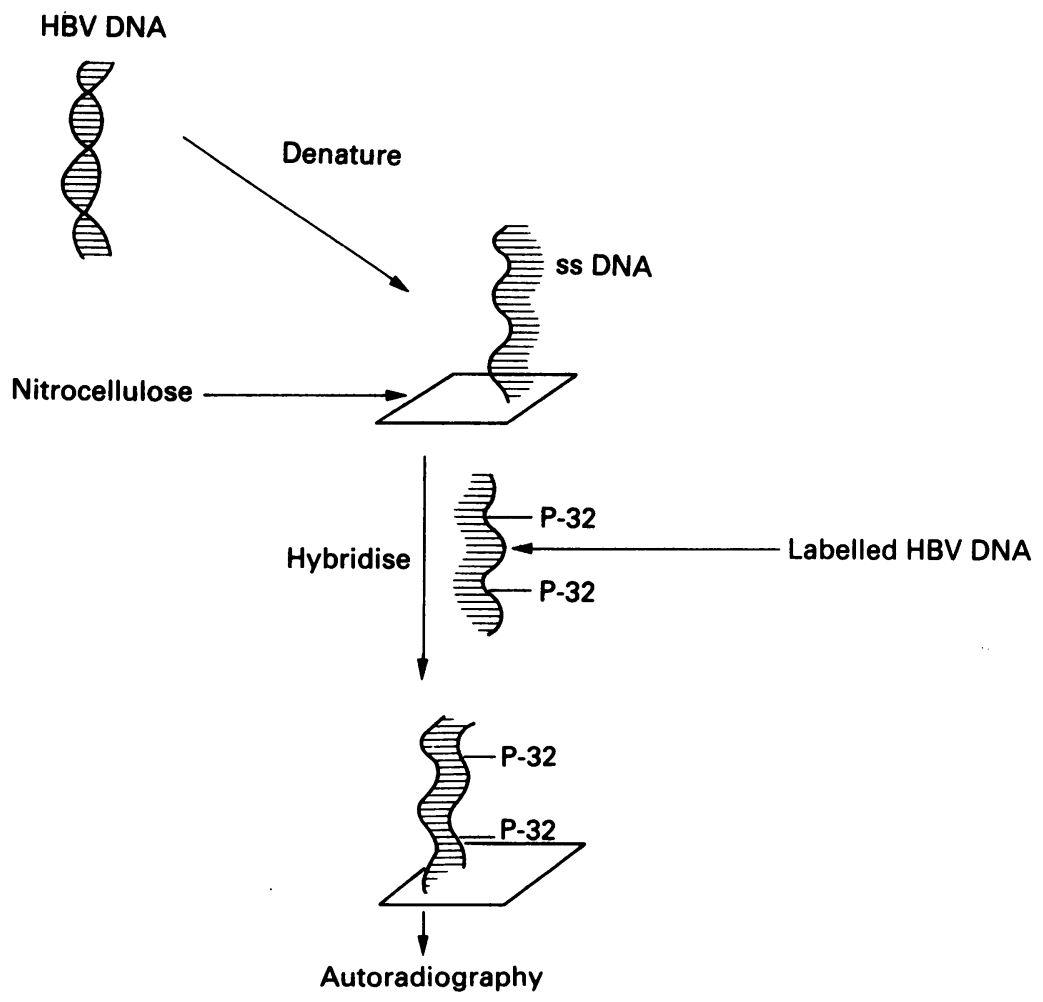

Figure 5 Nucleic acid hybridisation for detecting HBV DNA. labelled HBsAg conjugate. The concentration of the conjugate bound is directly proportional to the concentration of anti-HBs present in the serum sample. Results should be expressed as $\mathrm{mIU} / \mathrm{ml}$ of anti-HBs and although the results of long-term follow-up studies on the duration of immunity following $\mathrm{HBV}$ vaccination are not yet available some basic guidelines are given in table 2.

\section{Automated systems}

The IMx system (Abbott Laboratories, USA) which is a fully automated immunoassay analyser is used to perform microparticle enzyme immunoassays (MEIA). These assays use submicron particles, coated with antigen or antibody, as their solid phase. After the addition of the sample all subsequent procedures are performed in an MEIA reaction cell which is constructed of the sample well, dilution and reaction wells and a well containing a glass fibre filter. Immune complexes formed during incubation of the patient's serum with coated microparticles are captured on an inert glass fibre filter to which the microcarriers are transferred after incubation. Immune complexes are then detected with an alkaline phosphataselabelled conjugate which catalyses the hydrolysis of 4-methyl umbelliferyl phosphate to produce a fluorescent product, the intensity of which is measured in a fluorometer.

$H B V D N A$ and $H B V D N A$ polymerase The presence of HBV DNA, detected in samples of serum by means of molecular biological techniques, is the most reliable marker of infectivity and virus replication in $\mathrm{HBsAg}$ chronic carriers. $^{22}$ Although HBeAg is also used as a marker of viral replication it is not a reliable marker in patients infected with $\mathrm{HBeAg}$ minus mutants. The presence of serum HBV DNA in these patients is associated with persistence of viral replication. High concentrations of $\mathrm{HBV}$ DNA and low concentrations of alanine aminotransferase (ALT) are associated with minimal liver damage whereas low concentrations of HBV DNA in the presence of high concentrations of ALT are consistent with histologically apparent liver damage.

Nucleic acid hybridisation techniques for detecting HBV DNA use labelled complementary ssDNA to detect HBV DNA, rendered single stranded by denaturation and immobilised on nitrocellulose or nylon membranes ${ }^{23}$ (fig 5). HBV DNA may be obtained from the recombinant plasmid $\mathrm{pBR} 322-\mathrm{HBV}$, cloned in $E$ coli, and purified from the plasmid by cleavage with the restriction enzyme $\mathrm{XhOI}$ followed by gel electrophoresis. The resulting DNA may be radiolabelled by "nick translation"24 or by random priming with the Multiprime DNA Labelling Kit (Amersham, UK) to produce a DNA probe with specific activities $>10^{8} \mathrm{dpm} / \mu \mathrm{g}$ DNA.

Several methods for extracting HBV DNA from serum samples and performing the nucleic acid hybridisation assay have been described. ${ }^{25}{ }^{26}$ Briefly, DNA is purified from serum samples by digestion with Pronase followed by extraction with phenol. The DNA, 
Table 3 Serological profiles in HDV infection

\begin{tabular}{|c|c|c|c|c|c|}
\hline & $H B s A g^{\star}$ & $\underset{\operatorname{IgM}}{\operatorname{anti-HBC}}$ & HDAg† & $\underset{I g M}{\operatorname{anti-HD}}$ & $\begin{array}{l}\text { Total } \\
\text { anti-HD }\end{array}$ \\
\hline $\begin{array}{l}\text { Acute HBV/HDV conifection } \\
\text { Acute HBV/HDV superinfection }\end{array}$ & + & + & + & + & + \\
\hline $\begin{array}{l}\text { Acute HBV/HDV superinfection } \\
\text { Chronic HBV/HDV superinfection }\end{array}$ & $\begin{array}{l}+ \\
+\end{array}$ & $\overline{-}$ & $\stackrel{+}{-}$ & $\begin{array}{l}+ \\
+\end{array}$ & $\begin{array}{l}+ \\
+\end{array}$ \\
\hline
\end{tabular}

The expression of HBsAg may be depressed during active HDV replication

tHDAg is transient, 2-3 weeks in acute co- or superinfection.

†Anti-HD IgM is usually only present for $2-4$ weeks in coinfection but may be detected for more than 2 years in superinfections.

collected from the aqueous phase, is then precipitated with absolute alcohol and resuspended in a small volume of distilled water. The DNA samples are then applied to a nitrocellulose or nylon membrane, air dried, denatured and baked in a vacuum oven at $80^{\circ} \mathrm{C}$. Non-specific binding of the probe DNA may be minimised by pre-hybridising at $70^{\circ} \mathrm{C}$. The hybridisation mixture, containing the labelled probe DNA is heated to $100^{\circ} \mathrm{C}$ for $2-3$ minutes to render the DNA single stranded before being added to the pre-hybridised membrane at $37^{\circ} \mathrm{C}$. The membrane is incubated at $37^{\circ} \mathrm{C}$ overnight, washed to remove excess probe and autoradiographed at $-70^{\circ} \mathrm{C}$.

HBV DNA hybridisation is capable of detecting $0.1 \mathrm{pg}$ HBV DNA when the complementary DNA is labelled with the radioisotope $P$ 32. Although biotinylated DNA probes do not suffer from the problems of short shelf-life and safe handling associated with radiolabelled probes they may be less sensitive for detecting HBV DNA. ${ }^{27}$ Alternative non-radioactive probes such as those labelled with digoxigenin have been shown to be as sensitive as P-32 labelled probes for detecting HBV DNA. ${ }^{28}$

$H B V D N A$ polymerase: the presence of HBV DNA polymerase in the serum is an important marker of $\mathrm{HBV}$ replication and can be detected by its ability to synthesise DNA, incorporating a radiolabelled nucleotide, in vitro. ${ }^{29}$ The HBV DNA polymerase assay and the more sensitive HBV DNA hybridisation assay have been used to determine the efficacy of antiviral agents used in the treatment of HBV infection. ${ }^{30}$ The aim of antiviral chemotherapy is to disrupt viral replication by blocking viral polymerases more potently than cellular polymerases leading to the loss of HBeAg, HBV DNA and HBV DNA polymerase from the serum.

\section{The polymerase chain reaction}

The polymerase chain reaction (PCR) has been used by some researchers to detect HBV DNA in serum. ${ }^{31}$ This technique is used to amplify and make detectable low concentrations of HBV DNA undetectable by conventional nucleic acid hybridisation methods. Although PCR for detecting HBV DNA is not yet used widely, the increase in assay sensitivity and its ability to identify $\mathrm{HBsAg}$ carriers with a low level of viraemia may make it an exciting new tool for the laboratory diagnosis of $\mathrm{HBV}$ infection.

Hepatitis $D$ virus infection

Hepatitis D virus (HDV) is an incomplete RNA virus that depends on $\mathrm{HBV}$ to replicate. ${ }^{32}$
HDV infection may occur simultaneously with $\mathrm{HBV}$ infection or as a superinfection in chronic carriers of HBsAg. When infection occurs simultaneously liver disease may be no more severe than that seen in $\mathrm{HBV}$ infection alone $\mathrm{e}^{33}$ but a superinfection may increase the possibility of the patient progressing to chronic active hepatitis and cirrhosis. ${ }^{34}$

Three HDV serological markers are sought in the diagnosis of HDV infection and table 3 shows the different serological profiles seen in HDV and HBV simultaneous or coinfection and in acute or chronic HDV superinfection.

1 Blumberg BS, Alter HJ, Visnich S. A "new" antigen in leukemia sera. JAMA 1965;191:541-6.

2 Prince AM. An antigen detected in the blood during the incubation period of serum hepatitis. Proc Natl Acad Sci USA 1968;60:814-21.

3 Dane DS, Cameron $\mathrm{CH}$, Briggs $\mathrm{M}$. Virus-like particles in serum of patients with Australia-antigen-positive hepatitis. Lancet 1970;i:695.

4 Almeida JD, Rubenstein D, Stott E. New antigen-antibody system in Australia-antigen-positive hepatitis. Lancet $1971 ; \mathbf{i i}: 1224-7$.

5 Magnius LD, Espmark JA. New specificities in Australiaantigen-positive sera distinct from the LeBouvier determinants. J Immunol 1972;109:1017-21.

6 Burrell CJ, MacKay P, Greenaway PJ, Hofschneider PH, Murray K. Expression in Escherichia coli of hepatitis B Murray K. Expression in Escherichia coli of hepatitis B
virus DNA sequences cloned in plasmid pBR322. Nature virus DNA seque

7 Tilzey AJ, Laidler PW, Banatvala JE. Reactogenicity and immunogenicity of a yeast-derived recombinant DNA hepatitis vaccine in healthy young adults. In: Zuckerman AJ ed. Viral Hepatitis and Liver Disease, New York, Alan $R$ Liss 1988: 1047-53.

8 Carman WF, Thomas HC. Genetically defined variants of hepatitis B virus. Reviews in Medical Virology 1991;1: 29-39.

9 LeBouvier GL. The heterogeneity of Australia antigen. $J$ Infect Dis 1971;123:671-5.

10 Alter HJ, Holland PV, Purcell RH. Counterlectrophoresis for detection of hepatitis-associated antigen: methodology and comparison with gel diffusion and complement fixation. J Lab Clin Med 1971;77:1000-10.

11 Leach JM, Ruck BJ. Detection of hepatitis associated antigen by the latex agglutination test. $B M J 1971 ; 4: 597-8$.

12 Peterson DA, Froesner GG, Deinhardt FW. Evaluation of passive haemagglutination, solid-phase radioimmunoassay, and immunoelectroosmorphoresis for the detection of hepatitis B antigen. Appl Microbiol 1973;26:376-80.

13 Wreghitt TG, Cayzer I. A rapid haemagglutination test for the detection of HBsAg. Dev Biol Stand 1975;30:120-2.

14 Hollinger FB, Vorndam V, Dreesman GR. Assay of Australia antigen and antibody employing double-antibody solid-phase radioimmunoassay techniques and comparison with the passive hemagglutination methods. J Immunol 1971;107:1099-111.

15 Wolters G, Kuijpers L, Kacaki J, Schuurs A. Solid-phase enzyme immunoassay for detection of hepatitis B surface antigen. J Clin Pathol 1976;29:873-9.

16 Whitehead P, Thorpe GHG, Carter TJN, Groucutt C, Kricka LJ. Enhanced luminescence procedure for sensitive determination of peroxidase-labelled conjugates in immunoassay. Nature 1983;305:158-9.

17 Goodall AH, Miescher G, Meek FM, Janossy G, Thomas HC. Monoclonal antibodies in a solid-phase radiometric HC. Monoclonal antibodies in a solid-phase radio

18 Gatley S. A case for amplification. Medical Laboratory World 1986; Jan 27-28.

19 Guesdon JL, Ternynck T, Avrameas S. The use of avidinbiotin interaction in immunological techniques. $J$ Histochem Cytochem 1979;27:1131-9.

20 Jilg W, Schmidt M, Deinhardt F, Zachoval R. Hepatitis B vaccination: How long does protection last? Lancet 1984; ii:458.

21 Carman WF, Zanetti AR, Karayiannis $P$, et al. Virus induced escape mutants of hepatitis B virus. Lancet 1990;336:325-9.

22 Bonino F. The importance of hepatitis B virus viral DNA in serum and liver. $J$ Hepatol 1986;3:136-41.

23 Scotto J, Hadchouel M, Hery C, Yvart J, Tiollais P, Brechot C. Detection of hepatitis B virus DNA in serum by simple spot hybridization technique: comparison with results for other viral markers. Hepatology 1982;3:279-82.

24 Rigby PWJ, Dieckmann M, Rhodes C, Berg P. Labelling deoxyribonucleic acid to high specific activity in vitro by nick translation with DNA polymerase I. J Mol Biol 1977;113:237-51

25 Berninger M, Hammer M, Hoyer B, Gerin JL. An assay for the detection of the DNA genome of hepatitis $B$ virus in serum. $J$ Med Virol 1982;9:57-68.

26 Weller IVD, Fowler MJF, Monjardino J, Thomas HC. The detection of HBV-DNA in serum by molecular hybridisa- 
tion: A more sensitive method for the detection of complete HBV particles. J Med Virol 1982;9:273-80.

27 Saldanha JA, Karayannis P, Thomas HC, Monjardino JP. Use of biotinylated probes in serum hepatitis B virus DNA detection. J Virol Methods 1987;16:339.-42

28 Naoumov NV, Lau JYN, Daniels HM, Alexander GJM Willi Williams R. Detection or HBV DNA using a digoxigeninlabelled probe: A rapid technique without loss of sensi-
tivity. $J$ Hepatol 1991;12:382-5. tivity. J Hepatol 1991;12:382-5.

9 Feinstone SM, Barker LF, Purcell RH. Hepatitis A and B. In: Lennette EH, Schmidt NJ, eds. Diagnostic Procedures for Viral, Rickettsial and Chlamydial Infections. Washing ton: American Public Health Association, Inc 1979. 879-925

30 Scullard GH, Andres LL, Greenberg HB, et al. Antivira treatment of chronic hepatitis $B$ virus infection: Improvement in liver disease with interferon and adenine arabinoside. Hepatology 1981;1:228-32.

31 Manzin A, Salvoni G, Bagnarelli P, Menzo S, Carloni G Clementi $M$. A single-step DNA extraction procedure for the detection of serum hepatitis $B$ virus sequences by the polymerase chain reaction. J Virol Methods 1991;2: polymerase

32 Wang K, Choo Q, Weiner AJ, Ou J, Najarian RC, Thayer RM, et al. Structure, sequence and expression of the RM, et al. Structure, sequence and expression of the

33 Papaevangelou G, Tassopoulos N, RoumeliotouKarayannis A. Delta infection with hepatitis B. Lancet Karayannis

34 Rizzetto M. The delta agent. Hepatology 1983;5:729-37. 